\title{
Gender Bias in Textbooks and Test Items of English Language Learning in the Indonesian Context
}

\author{
Suhartono \\ Linguistic Department \\ University of Sebelas Maret \\ Surakarta, Indonesia
}

\author{
Diah Kristina \\ Linguistic Department \\ University of Sebelas Maret \\ Surakarta, Indonesia
}

\begin{abstract}
This study projected the aim at focusing on the analysis on gender bias in textbook tasks and test-items in printed national examination documents as well as the students' perception toward the bias. This study provides information about two issues: data sources and data analysis. The data were taken from senior high school textbooks and printed national examination documents. All the data were set up using content analysis. There are two types of gender bias which were mostly found in the textbooks and the test items: (1) the language use and (2) the representation (3) Students' Perceptions on Gender Bias on the Textbooks and Test Items. This study recommended that textbooks' author and publisher should pay more attention to the textbook compilations. The English teacher also should take into account the gender as the focus on their learning.
\end{abstract}

Keywords-gender bias; textbooks; test items; language use; representation

\section{INTRODUCTION}

Gender is a combination of nature and culture, biological traits as well as learned behaviors (Ryan in Ena, 2014). In Indonesia, these combinations result two kinds of genders accepted: male and female. According to World Trade Press (2010) Indonesia is categorized into patrilineal system in which males are very dominant except for some communities or ethnic groups such as Minangkabau and West Timor in which females are in charge of the household and males take their wife's surnames.

According to the latest of population census in 2010, the total number of Indonesia citizens are 237.641.326 citizens which are divided into 118, 010,413 females and 119,630, 913 males respectively. The numbers show that Indonesia, actually, can be categorized into quite balance or equal country in a matter of gender. The equality from the number of citizens, however, is not followed by the equality of several sectors especially in education.

Compared to ASEAN countries, the equality of gender in Education is left behind. According to Iskandar (2017) Indonesia is still experiencing gender inequality compared to ASEAN countries. Indonesia was ranked 88 in the world in 2016 in terms of gender inequality. This rank was higher than the Philippines (7) Laos (43), Singapore (55), Vietnam (65), and Thailand (71). It obviously showed that Indonesia needs much more attention to create equal gender especially in education.

In the last decade, however, Indonesia has come a long way in improving gender equity in education access. The improvement might result from a combination of several policies as like sustained national investments in education that have expanded the availability of schools in rural (ACDP, 2017) and outermost areas and lowered the direct and opportunity costs of schooling through School Operational Funding (BOS) as well as Scholarship policy (KIP) for poor people which enable them to continue their study as high as possible without worrying the school fees.

However, the Government needs to know that access alone does not equate to education outcomes and in recent years more attention has been given to quality, relevance and achievement (ACDP, 2017). Gender equality in education also encompasses girls' and boys' experiences in school, in terms of equal and fair treatment by teachers and the gender responsiveness of the curriculum, textbooks and learning materials, as well as the learning environment and education outcomes. Thus, students' experiences at school are expected giving big roles to the success. One of the students' learning experiences which can be optimized to achieve that goal deals with textbook and learning materials.

Textbooks and learning materials play an essential role in the process of teaching and learning in the classrooms. Textbooks are often used as the main sources of learning in Indonesia. It can be in the form of module, handbook, students' worksheet, compilation of test items, etc. Meanwhile, learning materials are any materials which can help the learners to learn. Campbell in Ena (2014) determined minimum qualitative criteria to select a good textbook. The first criterion is that the learning materials are unbiased and non -stereotypical. Secondly they should have comprehensive, complete, and inclusive view of society and its history. They should also have diverse viewpoints. They should not only represent the culture of the majority group. Good learning materials should build on and extend students' experiences. And finally, they should help students analyze and comprehend how real-life situations.

Based on these criteria, this study projected the aim at the study only in the first criteria. The writers focus the analysis 
on gender bias in textbook and test-items in printed national examination documents and students' perception toward the bias.

\section{Methodology}

This chapter provides information about two issues: data sources and data analysis. The data were taken from senior high school textbooks and printed national examination documents. The textbooks consist of the tenth and the eleventh grade students' modul published by the publishing team of Indonesian Ministry of Education and Culture. The books are used for all types of high schools including Senior High School (SMA), Islamic High School (MA), and Vocational School (SMK). While the National examination documents are printed national examination test items for SMA and MA as well as collection of test items for Vocational School.

To analysis the data, this present study was set up using content analysis as as Yeung (2013) said that content analysis has long been the widely adopted methodology to study textbooks. In fact, apart from textbooks, content analysis is also being adopted to analyze other forms of communications including newspaper, pictures, encyclopedias, television, and literary publications (Tang, in Hazel, 2014). Furthermore, Ferman \& Levin in Hazel (2014) mentioned that content analysis is an approach to collect data especially related to the textbooks.

\section{RESULTS AND DISCUSSION}

Curricullum has essential role to ensure both boys and girls have same oppportunities for obtaining success and achieving their goals at school. Teaching and learning activites as well as materials take big portion on determining those hits. Infact, even though the classroom activities have been set to make the students have same opportunities to take part in teaching and learning process equally, gender bias and stereotypes tend to appear thoroughly. This phenomena continously occurs since the teacher mostly get difficulty in controlling the situation because it comes from textbooks or printed documents whick are officially published by goverment which cannnot be revised directly such as questions or test items in textbooks and national examination documents.

There are two types of gender bias which were mostly found in the test items: (1) the language use and (2) the representation. It is in line with the findings of Mattu and Hussain's (2004) research on Gender Biases and Stereotypes in school texts. They mentioned that language uses and representation of sexes are inequity.

\section{A. Language Use}

A gender bias analysis of questions in the revised textbooks for the tenth grade students in SMA, SMK, MA and MAK in Indonesia undertaken in 2017 found significant gender bias Language use by the authors. It tends to portray the males as the dominant gender especially in the case of leadership and work achievement but inferior in language learning and social environment. On the other hand, the females are portrayed as inferiors in leadership and work achievement but superior in language learning and social environment. These positive and negative portrayals do not reflect real situation in the society since many studies shows various findings. Despite these attempts to provide greater gender balance, however, recent studies show that bias in textbooks and test items remains pervasive in many countries, including India, Iran, Pakistan and some developed countries such as Australia (Benavot, 2016).

Amruthraj (2017) found that women in india tend to have negative potrayals either in the text books or test items. In addition, Benavot (2016) stated that a study which was conducted in 2015 showed that Pakistan found no signifant changes in the negative portrayal toward women provided in text books since 2004. In Iran in 2012, the Ministry of Education displayed the males up to $80 \%$ in the text book and test items. In Australia, despite there being more females than males in the country, 2009 study revealed that $57 \%$ of the characters in textbooks were males especially in pit the domination in materials related to law, politics and goverment.

However, some countries are showing positive change, with textbooks reflecting gender equality and women and girls' active participation in society. In Jordan, women are portrayed as prime ministers, as fighters and pilots. In Palestine, they are shown as street demonstrators, and voting (Benavot, 2016). In Indonesia, the improvement of gender equality shows significant improvement even it is not huge.

\section{B. Representation}

The inequality of Gender representation in in textbook undoubtedly does exist. Ena (2014) in her study about gender roles representation in Indonesian school textbooks: a visual content analysis mentioned:

In terms of number, the images of men were more dominant than the images of women as shown in table All the English e-textbooks examined had depicted more male characters in their illustrations. E-textbooks one for grade ten; three for grade eleven; and eight for grade twelve had slightly higher number of male images. E-textbook one had 54.4 percent male and 45.5 percent female images. Etextbook three depicted 58.6 percent of men and 41.3 percent of women images. Similarly, e-textbook eight had 49.6percent images of men and 46.2 percent images of women. The other e-textbooks had bigger differences in number between male and female images shown as their illustrations. Male images were more dominant shown by significantly higher number of images in the illustrations of the e-textbooks. There were 1113 male images or 62.4 percent compared to 663 women images of 37.2 percent from the overall number of 1776 human images.

This finding found out that the representation of males in Indonesia text book is much greater than females. It is shown by the number of percentages in each category which are dominated by males. For example, in category of human images, male images lead up to 1113 images $(62.8 \%)$ compared to females which only reach 663 images $(37.2 \%)$. In other words, male images lead $450(25.6 \%)$ It indirectly indicates that males have tendency to be more superior and dominant to be subject of discussion. 
The test items in senior high school national examination academic year 2016-2017, it is widely known that the test were dominantly portrayed male as the superior human which possesses several positive characterization such us nationalism, full of skill in sport, hard worker, full of empathy, and possessing higher ability mathematics and science.

\section{Students' Perceptions on Gender Bias on the Textbooks and Test Items}

A number studies found out that gender bias in educational resources may affect learners negatively (Lewandowski, 2014). Harashima (2005, p. 1007) argued that it might be more difficult for female students to empathize with the characters in the textbook, therefore their motivation to study may be diminished. Recent studies, however, in some cases, female learners are portrayed as more dominant learners in language learning than male (Spada, 2014). Hence, it is important to bear in mind that no language is ever produced in a social vacuum, as even the grammatical structures commonly practiced in the EFL classroom are almost always people with individuals who are able to be recognized as male or female (Pawelczyk et al. 2014, pp. 50-51) which are usually biased. The gender bias in textbooks and test item psycologically affects the students in learning.

For example, Atha, one of the Indonesian female student in state senior high school in Kediri, East Java protested to her teacher about the language use in the textbooks especially in one of the dialogue she had to demonstrate with his friends in front of the class. She stated that in the dalogue only portrayed man as the one who always succed in business. She felt that it was unfair since she also had a goal in the future as successfull business women. So, she had trained herself to be business woman as early as possible that can help her to be more experienced to run her future business by helping her sister in online-shopping resellers. By the language uses in the textbooks which are dominantly put man as "destined" successful person in business, she finally asksed whether female could succed as the males do in work place.

On the other hand, Amar, a male students of computer engineering program in one of vocational high school in Kediri complained about his English textbook. He mentioned that the book always placed female students as the most competent students in English. He argued that it did not make a sense since it was againts belief and the reality. He believed that in order to succed In English, study hard and practice more and more were the keys. He added that in his class, male students were much more active than the female students. In could be proved from the English scores and trophies in English competition which dominantly achieved by male students. By the laguage uses which is portrayed in the textbooks, however, he recently came into hesitation about the keys of successful English learners. He was wondering wheter gender affects the achievement in English or not. In other pages of his books, he also found that the content of the book tried to discredit males as the one who were always do bad things and crimes at school as like bullying, smoking, and fighting. He was afraid that people who read the books would generate all male students especilly who vocational school students as the criminals. Hence, in this positition, he felt being intimidated by the books.

In another situation, Vina, a female senior high school students were curious about the representation of males in National Examination tests items. When his English teacher disccused the national examination test items in additional class for the preparation of real national examination, she found out that the representation of males are very dominant. From three text types ( biography, autobiography, and personal letter), all characters are males. After discussing with her deskmate, she came to negative conclusion that goverment (KEMENDIKBUD) concerned more to males than females in Education. She affraid her oppurtunity of being accepted in official school as like STAN and IPDN would also be limited.

This positive and negative portrayals which seems to be gender balance and inbalance do not reflect real situation in the world since many studies shows various findings. Despite these attempts to provide greater gender balance, however, recent studies show that bias in textbooks and test items remains pervasive in many countries, including India, Iran, Pakistan and some developed countries such as Australia (Benavot, 2016).

Amruthraj (2017) found that woman in india tend to have negative potrayals either in the text book or test items. In addition, Benavot (2016) stated that a study which was conducted in 2015 showed that Pakistan found no signifant changes in the negative portrayal toward women provided in text books since 2004. In Iran in 2012, the Ministry of Education displayed the males up to $80 \%$ in the text book and test items. In Australia, despite there being more females than males in the country, 2009 study revealed that $57 \%$ of the characters in textbooks were males especially in pit the domination in materials related to law, politics and goverment.

However, some countries are showing positive change, with textbooks reflecting gender equality and women and girls' active participation in society. In Jordan, women are portrayed as prime ministers, as fighters and pilots. In Palestine, they are shown as street demonstrators, and voting (Benavot, 2016). In Indonesia, the improvement of gender equality shows in the text book and test items significant improvement even it is not huge.

From the students' perception aboot the gender bias in text book above, it can be summarized that gender bias in the text books or test items may affect the students negatively. The students who feel being treated unfairly, intimidated harshly, and positioned inequally in the textbook as the main sources of learning may suffer long-term hesitation, unmotivated feeling, and loss of interest in learning English.

\section{CONCLUSION}

Based on the analysis of gender bias, it can be concluded that the language used by the author tends to portray the males as the superior gender especially in the case of leadership and work achievement but inferior in language learning and social environtment. On the other hand, the females are portrayed as inferiors in leadership and work achievement but superior in language learning and social 
environtment. Furthermore, related to gender bias in national examination test items, male portrayals tend to be very dominant since all text types related to the human description are discusing males as main characters.

Since gender bias in the text books or test items may affect the students negatively, the students who feel being treated unfairly, intimidated harshly, and positioned inequally in the textbook as the main sources of learning may suffer long-term hesitation, unmotivated feeling, and loss of interest in learning English. Textbook authors and publishers as well as National Education Standards Board (BSNP) should create balanced language uses and representations of males and females so that the English textbooks and national Examination test items that would be motivating and engaging for both male and female students. Balanced and accurate depictions in instructional materials and test items would make students possess awareness of the inequalities exist in Indonesian for long time.

\section{References}

ACDP. (2017). Rural and remote area education strategic planning study for Tanah Рapua, 2014. Jakarta: Balitbang.

Badan Pusat Statistik. (2010). Strategic data: statistics Indonesia. Jakarta: BPS-Statistic Indonesia.

Campbell, D.E. (2010). Choosing democracy: a practical guide to multicultural education. Boston: Allyn \& Bacon.

BSNP, Kementrian Pendidikan dan Kebudayaan. (2016). Soal Ujian Nasional Tahun Pelajaran 2016-2017 Bahasa Inggris SMA/MA Program IPA. Jakarta: Balitbang. Retrieved from http://www.m4th-lab.net/ 2017/10/download-soal-un-sma-tahun-2017-semua.html

Ena, o.t. (2014). Gender roles representation in indonesian school textbooks: visual content analysis. South Carolina: Createspace.

Ellis, Rod. (1997). Second language acquisition. Oxford: Oxford University Press.

Ferman, G. S., \& Levin, J. (1975). Social science research: a handbook for students. Cambridge: Halsted Press, New York.

Harashima, Hideto D. (2005). Sexual bias in an EFL textbook: a case study. In Bradford-watts, kim \& Ikeguchi, Cecilia \& Swanson, Malcolm (eds.), JALT2004 Conference Proceedings, 1005-1011. tokyo: jal.

Hazel, C.P.C. (2014). Gender representation in teaching materials of liberal studies in Hong Kong. A Dissertation Submitted in Partial Fulfillment of the Requirements for the Degree of Bachelor of Education. University of Hongkong, Hongkong.

Lewandowski, Marcin. (2014). Learner perceptions of gender representation in EFL grammar book. The poznań society for the advancement of the arts and Sciences, pp. 61-72.

Mattu, A, Hussain , N. (2004). Gender biases and stereotypes in school texts. Human Research Education, 7, 91-98.

Macaulay, Monica \& Brice, Colleen. (1997). Don't touch my projectile: gender bias and stereotyping in syntactic examples. Language, 73(4), 798-825.

Pawelczyk, Joanna \& Pakuła, Lukasz \& Sunderland,Jjane. 2014. Issues of power in relation to gender and sexuality in the eFl classroom: an overview. Journal of Gender and Power, 1, 49-66.

Ryan, M. (2010). Cultural studies: a practical introduction. Chichester: Wiley-Blackwell

Spada, N \& Lightbown, P.M. (2013). How language are learned: fourth edition. Oxford: Oxford University Press

Sunderland, Jane. (1992). Gender in the EFL classroom. ELT Journal, 46(1), 81-90.

Yeung, C., (2013). The representation of gender in junior secondary ELT text books in Hong Kong. Unpublished disertation. University of Hongkong. Hongkong.

Widiati, U. et. Al. (2017). Bahasa Inggris SMA/SMK/MA/ $M A K$ kelas $X$. Jakarta: Kementrian Pendidikan dan Kebudayaan.

Widiati, U. et. al. (2017). Bahasa Inggris SMA/SMK/MA/ MAK kelas XI. Kementrian Pendidikan dan Kebudayaan. 